\title{
Intermolecular perturbation in the self-assembly of melamine
}

\author{
A. N. Petelski ${ }^{1,3} \cdot$ Darío J. R. Duarte $^{2,3} \cdot$ S. C. Pamies ${ }^{1}$ N. M. Peruchena ${ }^{2,3}$. \\ G. L. Sosa ${ }^{1,3}$
}

Received: 15 October 2015 / Accepted: 16 December 2015

(C) Springer-Verlag Berlin Heidelberg 2016

\begin{abstract}
A theoretical study has been conducted on a set of supramolecular complexes based on 1,3,5-triazine-2,4,6triamine, or melamine $(\mathrm{M})$, with cyanuric acid $(\mathrm{CA})$, trithiocyanuric acid (TCA), and two mono-substituted derivatives of $\mathrm{CA}$ with chlorine $(\mathrm{CACl})$ and bromine $(\mathrm{CABr})$. The study was carried out on 12 complexes, $\mathrm{M} /(\mathrm{CA})_{n}$, M/ $(\mathrm{TCA})_{n}, \mathrm{M} /(\mathrm{CACl})_{n}, \mathrm{M} /(\mathrm{CABr})_{n}$, with $n=1,2$ and 3 , by the density functional theory employing the $\omega$-B97XD functional with the $6-311++\mathrm{G}(d, p)$ basis set. Information about the intermolecular perturbation over $\mathrm{M}$ and the interactions that drive the self-assembly of these species has been obtained from the quantum theory of atoms in molecules and a natural bond orbital analysis. The harmonic oscillator model of aromaticity, the para-delocalization index, the fluctuation aromatic index, and two electron
\end{abstract}

Published as part of the special collection of articles "CHITEL 2015 - Torino - Italy".

Electronic supplementary material The online version of this article (doi:10.1007/s00214-015-1795-3) contains supplementary material, which is available to authorized users.

\section{G. L. Sosa}

glsosa@frre.utn.edu.ar

1 Grupo de Investigación en Química Teórica y Experiental (QuiTEx), Facultad Regional Resistencia, Universidad Tecnológica Nacional, French 414, 3500 Resistencia, Chaco, Argentina

2 Laboratorio de Estructura Molecular y Propiedades (LEMYP), Área de Química Física, Facultad de Ciencias Exactas y Naturales y Agrimensura, Universidad Nacional del Nordeste, Avenida Libertad 5460, 3400 Corrientes, Argentina

3 IQUIBA-NEA (UNNE-CONICET), Avenida Libertad 5460, 3400 Corrientes, Argentina charge density descriptors were used to evaluate the aromaticity of $\mathrm{M}$ in each complex. Results show that the hydrogen and halogen (XBs) bond interactions, which direct the self-assembly process in these complexes, are anti-cooperative. Binding energies decrease in the following order: $\mathrm{M} /$ $(\mathrm{CA})_{n}>\mathrm{M} /(\mathrm{TCA})_{n}>\mathrm{M} /(\mathrm{CABr})_{n}>\mathrm{M} /(\mathrm{CACl})_{n}$ (for all values of $n$ ). Brominated CA arises as a potential compound to self-assembly with M via XBs.

Keywords Cyanuric acid · Supramolecular · Molecular building blocks $\cdot$ Hydrogen bond $\cdot$ Halogen bond

\section{Introduction}

The concept of supramolecular chemistry $[1,2]$ was introduced in the 1970s by Jean-Marie Lehn [3, 4], who, together with Pedersen and Clam, was awarded the Nobel Prize for their contribution to this field. The concept covers a vast area, but it can be briefly defined as a branch of chemistry that studies the chemical, physical, and biological characteristics of the chemical species called supramolecules. These entities are formed by molecules that are held together through non-covalent interactions [5], such as hydrogen bonds [6, 7] (HBs), halogen bonds $[8,9](\mathrm{XBs})$, and coordination interactions $[10,11]$ to name some of the main intermolecular forces.

One of the most significant current areas of research in the field of supramolecular chemistry is the study of selfassembly processes, which constitutes a powerful and highly effective method to create spontaneously complex structures [12-14]. In recent years, an increasing interest in nanoscale devices has stimulated research of intra- and intermolecular forces that control and lead to the creation of ordered one-, two- and three-dimensional nanostructures, 
from the self-assembly of small molecular building blocks $[13,15,16]$. In this field, 1,3,5-triazine-2,4,6-triamine, also known as melamine (M), and their derivatives have gained special attention in the last 20 years. Following the elucidation of the crystal structure of M [17], considerable research has been conducted on this compound. Dewar et al. [18] performed the first electronic structure study of M tautomeric forms. Later on, Meier and Coussens studied $\mathrm{M}$ molecular structure by ab initio, semiempirical, and molecular mechanics methods [19]. Wang et al. [20] studied the isolated $\mathrm{M}$ and two $\mathrm{M}$ derivatives through $\mathrm{ab}$ initio calculations, predicting that the three $\mathrm{M}$ amino groups have a pyramidal structure, two up and one down. Recently, $\mathrm{Li}$ et al. [21] studied the structural and spectral aspects of various M clusters by DFT calculations. Furthermore, experimental and theoretical studies of $\mathrm{M}$ structures on the $\mathrm{Au}(111)$ surface [22] have shown that $\mathrm{M}$ can form two different networks arranged by HBs on the surface, and the networks coexist despite the fact that one of them is less favored energetically.

On the other hand, several studies have been made regarding $\mathrm{M}$ interacting with other compounds due to their potential utility as self-assembly structures in nanotechnology and molecular electronics. Chiş et al. [23] have analyzed the vibrational and electronic aspects of $\mathrm{M}$ complexes with a perylene derivative and also the $\mathrm{M}$ dimer. Atalay et al. [24] have shown theoretical studies of the molecular structure and vibrational spectra of $\mathrm{M}$ diborate. Moreover, numerous studies have been reported in the solid state. Thomas et al. [25] have researched the structure of the 1:1 cocrystallized complex of $\mathrm{M}$ and uracil; Makowski et al. [26] reported two novel co-crystals between $\mathrm{M}$ and $\mathrm{N}$-heterocycles; Xu et al. [27] reported a 3D structure through multiple HBs and stacking interactions of pure $\mathrm{M}$ with halogen acids; and recently, Prior et al. [28] obtained an accurate measurement of the structure of the M-Cyanuric acid (CA) co-crystal after the first elucidation of its structure in 1990 [29].

Research to date has tended to focus on structure itself rather than on the interactions and the mutual effects among molecules, which govern the processes of molecular recognition and self-assembly [30]. Hence, an atomiclevel comprehension of the chemical nature, strength, and directionality of non-covalent interactions would lead to obtain major advantages to master the controlled design of new materials. This paper will emphasize the examination of intermolecular interactions between selected complexes bonded via HBs and XBs, which were assembled with $\mathrm{M}$ and a set of CA derivatives. In order to characterize these interactions and their mutual effects, an analysis of the electronic charge density distribution in the framework of the atoms in molecules (AIM) theory [31] and the natural bond orbital (NBO) analysis was performed. A set of 12<smiles>Nc1nc(N)nc(N)n1</smiles><smiles>O=c1[nH]c(=O)[nH]c(=O)[nH]1</smiles><smiles></smiles><smiles>O=c1[nH]c(=O)n(Cl)c(=O)[nH]1</smiles><smiles>O=c1[nH]c(=O)n(Br)c(=O)[nH]1</smiles>

Fig. 1 Molecular structures of a melamine, b cyanuric acid, c trithiocianuric acid, d 1-chloro-1,3,5-triazinane-2,4,6-trione, and e 1-bromo-1,3,5-triazinane-2,4,6-trione

complexes was selected, comprising $\mathrm{M}$, cianuric acid (CA), and three derivatives of CA that can potentially be assembled with $\mathrm{M}$, that is, trithiocyanuric acid (TCA) and two mono-halogenated derivatives of $\mathrm{CA}$, a chlorinated $(\mathrm{CACl})$ and a brominated (CABr; see Fig. 1), that is: $\mathrm{M} /(\mathrm{CA})_{n}, \mathrm{M} /$ $(\mathrm{TCA})_{n}, \mathrm{M} /(\mathrm{CACl})_{n}, \mathrm{M} /(\mathrm{CABr})_{n}$, with $n=1,2$ and 3.

Finally, in order to obtain more information about the intermolecular perturbation on $\mathrm{M}$, its aromaticity in each complex through various well-known aromaticity indices was evaluated: one index based on structural criteria, the harmonic oscillator model of aromaticity [32, 33] (HOMA), and two indices based on the QTAIM, the paradelocalization index [34] (PDI) and the fluctuation aromatic index [35] (FLU). They have been tested for a great variety of compounds and have shown good correlation with other indices. In addition, two charge density descriptors were used: the curvature of electron density perpendicular to ring plane $\left(\lambda_{3}\right)$ at the ring critical point (RCP) and the electron density $(\rho)$ at the RCP. In their study of benzenoid hydrocarbons, Howard and Krygowski [36] reported that these properties correlate well with the HOMA index aromaticity.

\section{Computational details}

The complexes were assembled placing $\mathrm{M}$ with each molecule of the selected set in order to form a dimer, and then the $\mathrm{HB}$ sites of $\mathrm{M}$ were saturated with each compound to form a trimer and finally a tetramer. Calculations were performed using the Gaussian 03 suite of programs [37]. The geometries of all monomers and complexes were fully optimized without any constraint, using the $\omega$-B97XD hybrid functional from Head-Gordon et al. [38] with the $6-311++\mathrm{G}(d, p)$ basis set (Cartesian coordinates are given in the electronic supplementary material). Since this functional includes empirical dispersion and correction on 
long-range interactions, it is potentially suitable for the description of hydrogen bonds [21]. Furthermore, it has been shown that the $\omega$-B97XD functional is also suitable for the description of halogen bonds [39]. The minimum energy nature of the optimized structures was verified using the vibrational frequency analysis.

The binding energies (BE) were obtained at the same level of theory using the supermolecular approach, which is calculated as the difference between the total energy of the complex and the sum of total energies of the isolated monomers (Eq. 1). Binding energies have also been corrected for the basis set superposition error (BSSE) within the approach of Boys and Bernardi [40].

$\mathrm{BE}=E_{\mathrm{M} /(\mathrm{C})_{n}}-\left(E_{\mathrm{M}}+n \times E_{\mathrm{C}}\right)$

where $n$ is the number of monomers around melamine, the sub-index $\mathrm{M}$ refers to melamine and $\mathrm{C}$ refers to either the subunit $\mathrm{CA}$ or its derivatives (TCA, $\mathrm{CACl}$ or $\mathrm{CABr}$ ). With these values, the $\mathrm{BE}$ per monomer added $\left(\mathrm{BE}_{\mathrm{PM}}\right)$ was also calculated by Eq. 2 .

$\mathrm{BE}_{\mathrm{PM}}=E_{\mathrm{M} /(\mathrm{C})_{n}}-E_{\mathrm{M} /(\mathrm{C})_{n-1}}-E_{\mathrm{C}}$

The topology analysis was carried out within the QTAIM with the AIMAll program [41], using the wave functions generated from the $\omega-\mathrm{B} 97 \mathrm{XD} / 6-311++\mathrm{G}(d, p)$ calculations. The optimized geometries were also used to perform a NBO analysis with NBO 3.1 program [42] as implemented in Gaussian 03 [37].

The aromaticity of the $\mathrm{M}$ ring was evaluated using geometric criteria by means of HOMA [32, 33] taking $R_{\mathrm{C}-\mathrm{N}}=1.334 \AA$ as reference value; topological criteria by means of PDI [34] and FLU [35] (taking a delocalization index $\delta_{\text {ref }}(\mathrm{C}, \mathrm{N})=1.566$ as reference value); and two charge density descriptors: $\lambda_{3}$ and $\rho$ at the RCP. All aromaticity descriptors were calculated with Multiwfn program [43].

\section{Results and discussion}

\subsection{Energetic and geometrical parameters}

Figure 2 shows the optimized geometries for the complexes studied in this work; for simplicity, an example of the $\mathrm{M} /(\mathrm{CA})_{n}$ set of complexes is shown. Binding energies with BSSE correction are given in Table 1 and the selected optimized geometrical parameters of interactions $\mathrm{D}-\mathrm{X} \cdots \mathrm{A}$ (where $\mathrm{D}=$ donor, $\mathrm{X}=\mathrm{H}, \mathrm{Cl}$ o $\mathrm{Br}$, and $\mathrm{A}=$ acceptor) are given in Table 2. These parameters refer to the $\mathrm{X} \cdots \mathrm{A}$ intermolecular distance, the $\mathrm{D}-\mathrm{X}$ bond length, and the $\alpha$ equilibrium angles, D-X ‥A. $\Delta d_{\mathrm{VdW}}(\mathrm{X} \cdots \mathrm{A})$ represents the difference between the sum of $A$ and $X$ Van der Waals radii [44] and the $\mathrm{X} \cdots \mathrm{A}$ intermolecular distances, and $\Delta d(\mathrm{D}-\mathrm{X})$
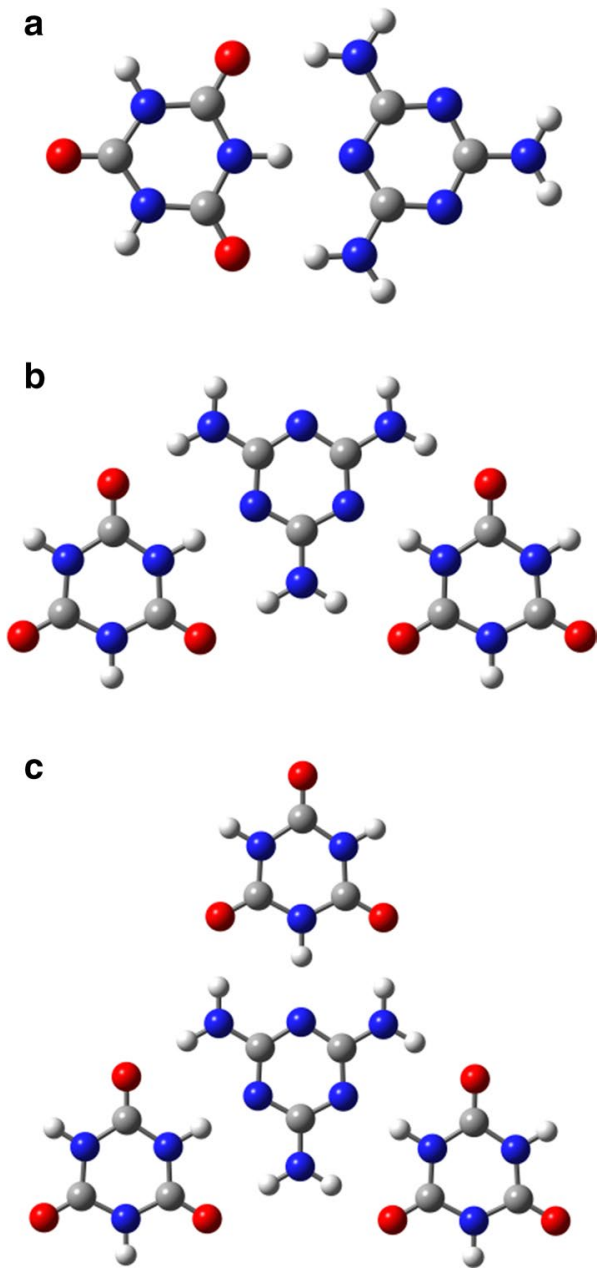

Fig. 2 Optimized geometries of a M/CA, b $\mathrm{M} /(\mathrm{CA})_{2}$, and $\mathbf{c} \mathrm{M} /(\mathrm{CA})_{3}$ complexes at $\omega$-B97XD/6-311++G** level of theory

Table 1 Binding energies calculated at $\omega-\mathrm{B} 97 \mathrm{XD} / 6-311++\mathrm{G}^{* *}$ level and corrected by counterpoise

\begin{tabular}{llll}
\hline Complex & $\mathrm{BE}$ & $\mathrm{BE}_{\text {corr }}$ & $\mathrm{BE}_{\mathrm{PM}}$ \\
\hline $\mathrm{M} / \mathrm{CA}$ & -20.21 & -19.33 & -20.21 \\
$\mathrm{M} /(\mathrm{CA})_{2}$ & -39.75 & -37.98 & -19.54 \\
$\mathrm{M} /(\mathrm{CA})_{3}$ & -58.57 & -55.87 & -18.82 \\
$\mathrm{M} / \mathrm{TCA}$ & -15.38 & -14.33 & -15.38 \\
$\mathrm{M} /(\mathrm{TCA})_{2}$ & -29.97 & -27.76 & -14.58 \\
$\mathrm{M} /(\mathrm{TCA})_{3}$ & -40.94 & -37.81 & -10.98 \\
$\mathrm{M} / \mathrm{CACl}$ & -8.91 & -8.05 & -8.91 \\
$\mathrm{M} /(\mathrm{CACl})_{2}$ & -17.44 & -15.79 & -8.53 \\
$\mathrm{M} /(\mathrm{CACl})_{3}$ & -25.70 & -23.12 & -8.26 \\
$\mathrm{M} / \mathrm{CABr}$ & -13.78 & -13.06 & -13.78 \\
$\mathrm{M} /(\mathrm{CABr})_{2}$ & -25.77 & -24.38 & -11.99 \\
$\mathrm{M} /(\mathrm{CABr})_{3}$ & -36.68 & -34.67 & -10.91 \\
\hline $\mathrm{Al}$ & & &
\end{tabular}

All values are in $\mathrm{kcal} / \mathrm{mol}$ 
Table 2 Selected geometric parameters of (a) $\mathrm{M} /(\mathrm{CA})_{n}$, (b) $\mathrm{M} /(\mathrm{TCA})_{n}$, (c) $\mathrm{M} /(\mathrm{CACl})_{n}$, (d) $\mathrm{M} /(\mathrm{CABr})_{n}$ complexes calculated at $\omega$-B97XD/6$311++\mathrm{G}^{* *}$ level

\begin{tabular}{|c|c|c|c|c|c|c|}
\hline Complex & $D-X \cdots A$ & $d(\mathrm{X} \cdots \mathrm{A})$ & $\Delta d_{\mathrm{VdW}}(\mathrm{X} \cdots \mathrm{A})$ & $d(\mathrm{D}-\mathrm{X})$ & $\Delta d(\mathrm{D}-\mathrm{X})$ & $\alpha \mathrm{D}-\mathrm{X} \cdots \mathrm{A}$ \\
\hline \multicolumn{7}{|l|}{ (a) } \\
\hline \multirow[t]{3}{*}{$\mathrm{M} / \mathrm{CA}$} & $\mathrm{N}-\mathrm{H} \cdots \mathrm{N}$ & 1.768 & 0.982 & 1.058 & 0.048 & 179.99 \\
\hline & $\mathrm{N}-\mathrm{H} \cdots \mathrm{O}$ & 1.938 & 0.782 & 1.013 & 0.009 & 175.29 \\
\hline & $\mathrm{N}-\mathrm{H} \cdots \mathrm{O}$ & 1.938 & 0.782 & 1.013 & 0.009 & 175.29 \\
\hline \multirow[t]{3}{*}{$\mathrm{M} /(\mathrm{CA})_{2}^{\mathrm{a}}$} & $\mathrm{N}-\mathrm{H} \cdots \mathrm{N}$ & 1.786 & 0.964 & 1.054 & 0.045 & 179.99 \\
\hline & $\mathrm{N}-\mathrm{H} \cdots \mathrm{O}$ & 1.930 & 0.790 & 1.013 & 0.010 & 176.00 \\
\hline & $\mathrm{N}-\mathrm{H} \cdots \mathrm{O}$ & 1.948 & 0.772 & 1.013 & 0.010 & 177.73 \\
\hline \multirow[t]{3}{*}{$\mathrm{M} /(\mathrm{CA})_{3}^{\mathrm{a}}$} & $\mathrm{N}-\mathrm{H} \cdots \mathrm{N}$ & 1.801 & 0.949 & 1.052 & 0.043 & 179.97 \\
\hline & $\mathrm{N}-\mathrm{H} \cdots \mathrm{O}$ & 1.939 & 0.781 & 1.013 & 0.010 & 178.66 \\
\hline & $\mathrm{N}-\mathrm{H} \cdots \mathrm{O}$ & 1.939 & 0.781 & 1.013 & 0.010 & 178.66 \\
\hline \multicolumn{7}{|l|}{ (b) } \\
\hline \multirow[t]{3}{*}{ M/TCA } & $\mathrm{N}-\mathrm{H} \cdots \mathrm{N}$ & 1.779 & 0.971 & 1.057 & 1.057 & 179.98 \\
\hline & $\mathrm{N}-\mathrm{H} \cdots \mathrm{S}$ & 2.510 & 0.490 & 1.011 & 1.011 & 157.47 \\
\hline & $\mathrm{N}-\mathrm{H} \cdots \mathrm{S}$ & 2.511 & 0.489 & 1.011 & 1.011 & 157.36 \\
\hline \multirow[t]{3}{*}{$\mathrm{M} /(\mathrm{TCA})_{2}^{\mathrm{a}}$} & $\mathrm{N}-\mathrm{H} \cdots \mathrm{N}$ & 1.816 & 0.934 & 1.051 & 1.051 & 179.30 \\
\hline & $\mathrm{N}-\mathrm{H} \cdots \mathrm{S}$ & 2.489 & 0.511 & 1.012 & 1.012 & 159.61 \\
\hline & $\mathrm{N}-\mathrm{H} \cdots \mathrm{S}$ & 2.522 & 0.478 & 1.012 & 1.012 & 154.61 \\
\hline \multirow[t]{9}{*}{$\mathrm{M} /(\mathrm{TCA})_{3}$} & $\mathrm{~N}-\mathrm{H} \cdots \mathrm{N}$ & 1.812 & 0.938 & 1.051 & 0.041 & 178.00 \\
\hline & $\mathrm{N}-\mathrm{H} \cdots \mathrm{S}$ & 2.487 & 0.513 & 1.011 & 0.008 & 162.34 \\
\hline & $\mathrm{N}-\mathrm{H} \cdots \mathrm{S}$ & 2.614 & 0.386 & 1.011 & 0.007 & 144.99 \\
\hline & $\mathrm{N}-\mathrm{H} \cdots \mathrm{N}$ & 1.819 & 0.931 & 1.051 & 0.041 & 179.76 \\
\hline & $\mathrm{N}-\mathrm{H} \cdots \mathrm{S}$ & 2.508 & 0.492 & 1.011 & 0.007 & 156.39 \\
\hline & $\mathrm{N}-\mathrm{H} \cdots \mathrm{S}$ & 2.522 & 0.478 & 1.012 & 0.009 & 154.67 \\
\hline & $\mathrm{N}-\mathrm{H} \cdots \mathrm{N}$ & 2.358 & 0.392 & 1.027 & 0.017 & 177.33 \\
\hline & $\mathrm{N}-\mathrm{H} \cdots \mathrm{S}$ & 2.363 & 0.637 & 1.012 & 0.008 & 170.00 \\
\hline & $\mathrm{N}-\mathrm{H} \cdots \mathrm{S}$ & 2.364 & 0.636 & 1.012 & 0.008 & 169.50 \\
\hline \multicolumn{7}{|l|}{ (c) } \\
\hline $\mathrm{M} / \mathrm{CACl}$ & $\mathrm{N}-\mathrm{Cl} \cdots \mathrm{N}$ & 2.526 & 0.774 & 1.728 & 0.034 & 179.81 \\
\hline $\mathrm{M} /(\mathrm{CACl})_{2}^{\mathrm{a}}$ & $\mathrm{N}-\mathrm{Cl} \cdots \mathrm{N}$ & 2.554 & 0.746 & 1.723 & 0.029 & 176.99 \\
\hline $\mathrm{M} /(\mathrm{CACl})_{3}^{\mathrm{a}}$ & $\mathrm{N}-\mathrm{Cl} \cdots \mathrm{N}$ & 2.568 & 0.732 & 1.721 & 0.026 & 179.97 \\
\hline \multicolumn{7}{|l|}{ (d) } \\
\hline \multirow[t]{3}{*}{$\mathrm{M} / \mathrm{CABr}$} & $\mathrm{N}-\mathrm{Br} \cdots \mathrm{N}$ & 2.399 & 1.001 & 1.927 & 0.078 & 179.97 \\
\hline & $\mathrm{N}-\mathrm{H} \cdots \mathrm{Br}$ & 2.737 & 0.313 & 1.006 & 0.003 & 120.46 \\
\hline & $\mathrm{N}-\mathrm{H} \cdots \mathrm{Br}$ & 2.739 & 0.311 & 1.006 & 0.003 & 120.44 \\
\hline \multirow[t]{3}{*}{$\mathrm{M} /(\mathrm{CABr})_{2}^{\mathrm{a}}$} & $\mathrm{N}-\mathrm{Br} \cdots \mathrm{N}$ & 2.447 & 0.953 & 1.910 & 0.061 & 179.62 \\
\hline & $\mathrm{N}-\mathrm{H} \cdots \mathrm{Br}$ & 2.746 & 0.304 & 1.007 & 0.003 & 121.64 \\
\hline & $\mathrm{N}-\mathrm{H} \cdots \mathrm{Br}$ & 2.754 & 0.296 & 1.007 & 0.003 & 122.29 \\
\hline \multirow[t]{3}{*}{$\mathrm{M} /(\mathrm{CABr})_{3}^{\mathrm{a}}$} & $\mathrm{N}-\mathrm{Br} \cdots \mathrm{N}$ & 2.500 & 0.900 & 1.898 & 1.898 & 179.92 \\
\hline & $\mathrm{N}-\mathrm{H} \cdots \mathrm{Br}$ & 2.765 & 0.285 & 1.007 & 1.007 & 123.53 \\
\hline & $\mathrm{N}-\mathrm{H} \cdots \mathrm{Br}$ & 2.764 & 0.286 & 1.007 & 1.007 & 123.52 \\
\hline
\end{tabular}

Distances in angstrom and angles in degrees

a All other interactions are essentially equal due to symmetry reasons represents the variations in the bond donor distance upon complexation, that is, the difference between the distance $d(\mathrm{D}-\mathrm{X})$ in the complexes and in the isolated monomers.

As can be seen in Table 1, through the binding energy analysis, all these complexes are stabilized by HBs and XBs interactions. In the bimolecular complexes, the strength of these interactions decreases in the following order: M/CA > M/TCA > M/CABr $>\mathrm{M} / \mathrm{CACl}$. This order is kept as the number of monomers around $\mathrm{M}$ increases. The most stabilized system is M/CA, probably due to the special set of highly directional HBs. It is worth noting that upon addition of monomers to the bimolecular complex, 
Fig. $3 \mathrm{M} /(\mathrm{TCA})_{n}$ complexes. a Top view and $\mathbf{b}$ side view of M/TCA complex. c Top view and $\mathbf{d}$ side view of $\mathrm{M} /(\mathrm{TCA})_{2}$ complex. e Top view and $\mathbf{f}$ side view of $\mathrm{M} /(\mathrm{TCA})_{3}$ complex

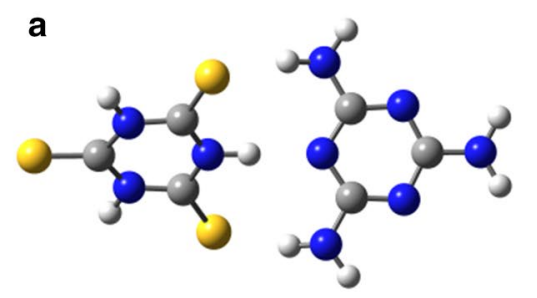

b
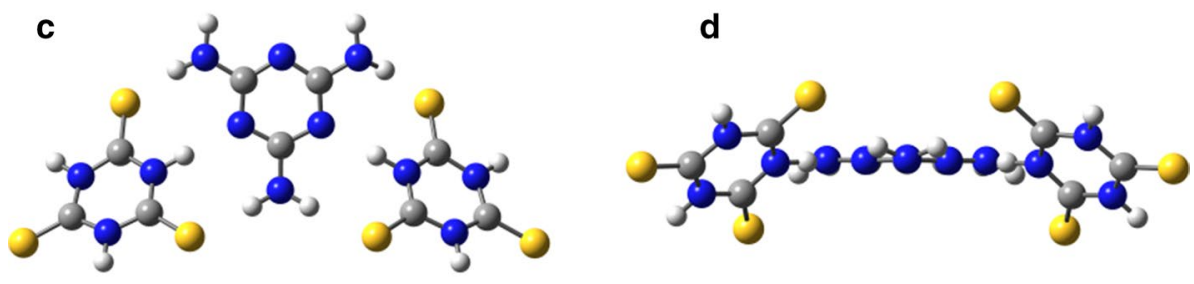

e

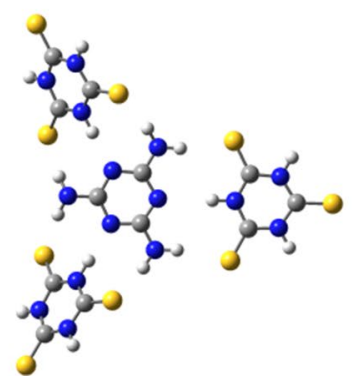

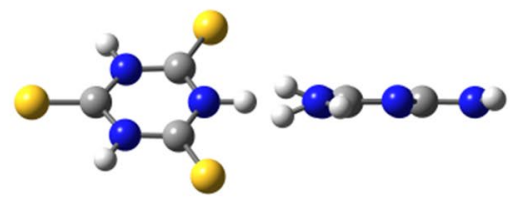

d

$f$

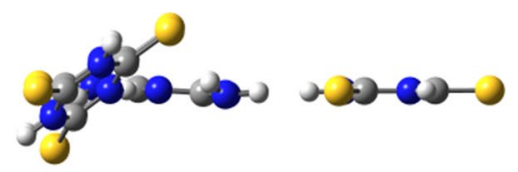

the average interaction energy decreases (see $\mathrm{BE}_{\mathrm{PM}}$ values), which means that the total interaction energies of tri and tetramolecular complexes are smaller than the sum of the individual interaction energies of the respective adducts. These results suggest that an anti-cooperative effect is operating.

Observation of geometrical parameters reported in Table 2 shows that in all cases a penetration of electronic densities of atoms $\mathrm{A}$ and $\mathrm{X}$ is evidenced, by interpreting $\Delta d_{\mathrm{VdW}}(\mathrm{X} \cdots \mathrm{A})$ values. The highest values of $\Delta d_{\mathrm{VdW}}(\mathrm{X} \cdots \mathrm{A})$ are reached in the $\mathrm{M} / \mathrm{CABr}$ systems followed by $\mathrm{M} / \mathrm{CA}$ systems. It can be seen from Table $2 \mathrm{a}-\mathrm{d}$ that in all complexes, as the number of CA monomers increases, the $\mathrm{X} \cdots \mathrm{A}$ distance of the $\mathrm{D}-\mathrm{X} \cdots \mathrm{A}$ interactions increases linearly. This does not correspond with the cooperative effect of HBs and $\mathrm{XBs}$ interactions expected in self-assembly systems, i.e., $\mathrm{X}$...A distances decrease as the cluster size increases [4548]. Thus, both energetic and geometrical criteria suggest a negative cooperativity of the interactions in these systems.

On the other hand, an elongation of distances D-X (positive values of $\Delta d(\mathrm{D}-\mathrm{X})$ ) is observed in all complexes. The stretchiness of D-X lengths correlates fairly well with the binding energies, taking into account the $\mathrm{N}-\mathrm{X} \cdots \mathrm{N}$ interaction. The values of $\Delta d(\mathrm{D}-\mathrm{X})$ are higher in the halogenated compounds. In addition, it can be seen that when the cluster size increases, distance length DX decreases, contrarily, again, to the cooperativity of HBs.
One final point concerning geometry is that all systems show coplanarity except the set of $\mathrm{M} /(\mathrm{TCA})_{n}$ complexes. This finding results are interesting, since Ranganathan et al. [49] have found that the crystal of the adduct M/TCA has the same spatial arrangement of molecules as the M/CA crystal, that is, all rings are coplanar. Our calculations, however, have shown that the M/TCA coplanar adduct is a transition state, since an imaginary frequency is observed, whereas the anticoplanar adduct is a minimum (see Fig. 3a). This behavior could be explained by a close packing process of molecules in the crystal state. The first and the second molecule of TCA are bound to $\mathrm{M}$ almost perpendicularly (see Fig. 3a-c) with regard to the $\mathrm{M}$ ring, and the angle between the two ring planes is $130^{\circ}$. This allows a greater approach between molecules leading to a $\mathrm{N}$... N intermolecular distance (2.929 $\AA$ ) shorter than in the coplanar dimer $(3.430 \AA)$, as indicated by our calculations, while the experimental distance value is $2.88 \AA$ [49]. It is worth emphasizing that despite the fact that coplanar dimer is a transition state, the third molecule of TCA interacts with M coplanarly (see Fig. 3e, f). In this last case, amino groups adopt a pyramidal form that probably contributes to this geometry.

\subsection{Local topological properties}

The Quantum Theory of Atoms in Molecules (QTAIM) of Bader [31] provides a rigorous definition of the chemical 


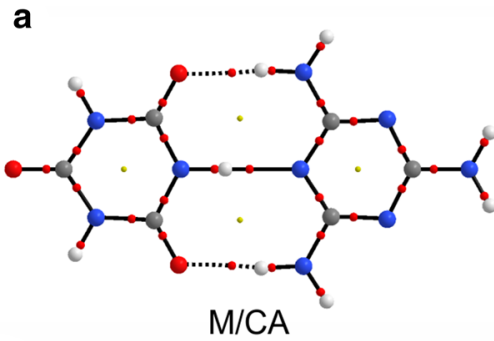

b

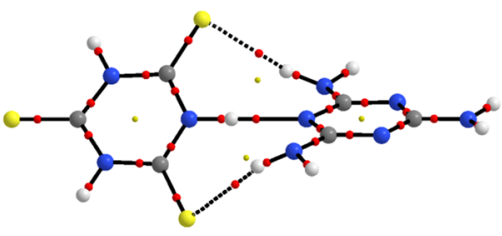

M/TCA

c

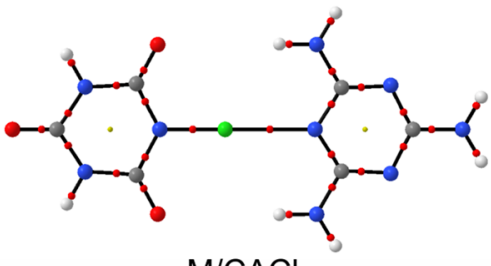

$\mathrm{M} / \mathrm{CACl}$

d

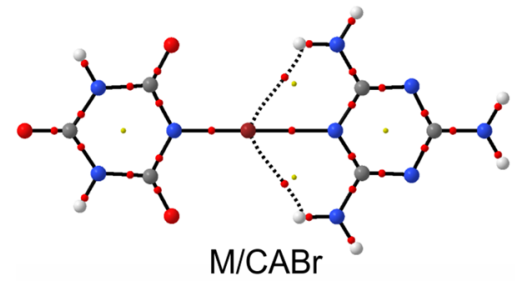

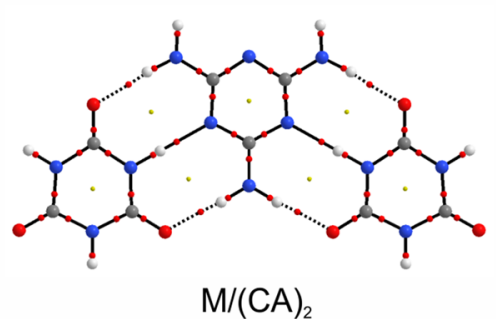

$\mathrm{M} /(\mathrm{CA})_{2}$

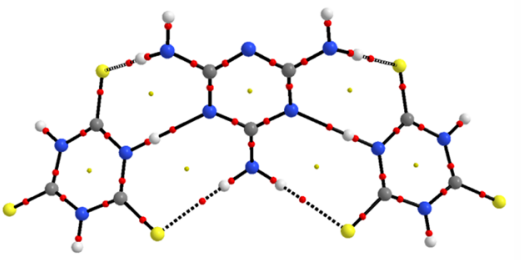

$\mathrm{M} /(\mathrm{TCA})_{2}$

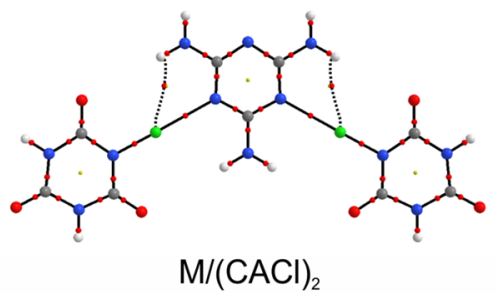

$\mathrm{M} /(\mathrm{CACl})_{2}$

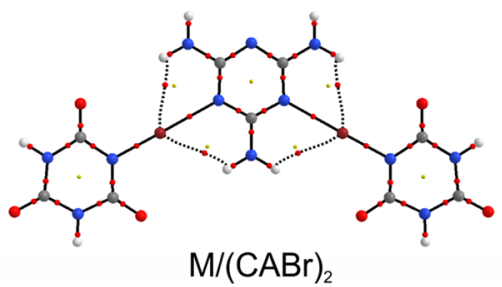

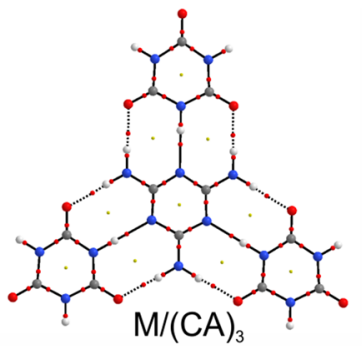

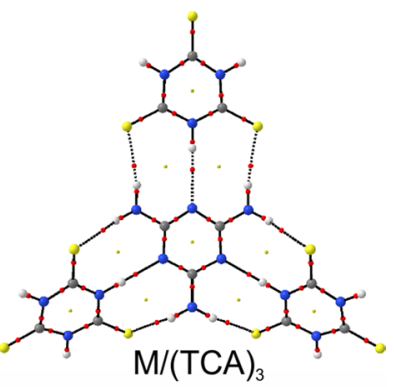

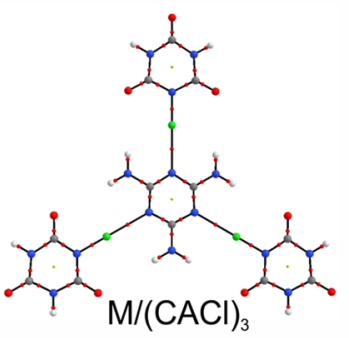

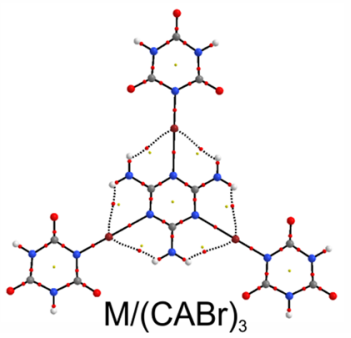

Fig. 4 Molecular graphs (network of bond paths linking pairs of neighboring nuclei) of melamine complexes. Small red dots indicate bond critical points and yellow dots indicate ring critical points. a $\mathrm{M} /(\mathrm{CA})_{n}, \mathbf{b} \mathrm{M} /(\mathrm{TCA})_{n}, \mathbf{c} \mathrm{M} /(\mathrm{CACl})_{n}$, and d M/(CABr $)_{n}$

concepts of atom, bond, and structure. This theory has been used successfully for the characterization of HBs and XBs interactions through a set of local topological properties calculated at bond critical points (BCP) of electron charge density and a set of integrated atomic properties on atomic basins $[50,51]$. In this work, the electron charge density $\rho\left(\mathbf{r}_{\mathrm{c}}\right)$, which measures the accumulation of charge between the bonded nuclei and reflects the bond strength; the Laplacian of the electron density $\nabla^{2} \rho\left(\mathbf{r}_{\mathrm{c}}\right)$ that provides information about the local charge concentration $\left(\nabla^{2} \rho\left(\mathbf{r}_{\mathrm{c}}\right)<0\right)$ or depletion $\left(\nabla^{2} \rho\left(\mathbf{r}_{\mathrm{c}}\right)>0\right)$; the densities of kinetic energy, $G\left(\mathbf{r}_{\mathrm{c}}\right)$; the densities of potential energy, $V\left(\mathbf{r}_{\mathrm{c}}\right)$; and the total electronic energy density $H\left(\mathbf{r}_{\mathrm{c}}\right)=V\left(\mathbf{r}_{\mathrm{c}}\right)+G\left(\mathbf{r}_{\mathrm{c}}\right)$, were used to analyze the nature of the interactions that occur in the different complexes.

The molecular graphs of all complexes are displayed in Fig. 4, and the local properties calculated at BCP are given in Table 3a-d. In all the complexes studied here, the criteria proposed by Popelier [51] that describe HB formation are fulfilled; that is, BCP properties present $\rho\left(\mathbf{r}_{\mathrm{c}}\right)$ values relatively low which range from 0.01 to $0.06 \mathrm{au}$; positive values of $\nabla^{2} \rho\left(\mathbf{r}_{\mathrm{c}}\right)$ that range from 0.02 to 0.1 au. Thus, BCP values are typical of closed shell interactions and correlate fairly well with values reported for similar interactions [52-54].

As can be seen in Fig. 4a, in complex mediated hydrogen bonds, three HB interactions occur for every added 
Table 3 Local properties at D-X ‥A bond critical points in (a) M/ $(\mathrm{CA})_{n}$, (b) $\mathrm{M} /(\mathrm{TCA})_{n}$, (c) $\mathrm{M} /(\mathrm{CACl})_{n}$, (d) $\mathrm{M} /(\mathrm{CABr})_{n}$ complexes

\begin{tabular}{|c|c|c|c|c|c|}
\hline Complex & Interaction & $\rho\left(\mathrm{r}_{\mathrm{c}}\right)$ & $\nabla^{2} \rho\left(\mathrm{r}_{\mathrm{c}}\right)$ & $V\left(\mathrm{r}_{\mathrm{c}}\right)$ & $H\left(\mathrm{r}_{\mathrm{c}}\right)$ \\
\hline \multicolumn{6}{|l|}{ (a) } \\
\hline \multirow[t]{3}{*}{$\mathrm{M} / \mathrm{CA}$} & $\mathrm{N}-\mathrm{H} \cdots \mathrm{N}$ & 0.0466 & 0.0951 & -0.0391 & -0.0077 \\
\hline & $\mathrm{N}-\mathrm{H} \cdots \mathrm{O}$ & 0.0247 & 0.0927 & -0.0183 & 0.0024 \\
\hline & $\mathrm{N}-\mathrm{H} \cdots \mathrm{O}$ & 0.0247 & 0.0927 & -0.0183 & 0.0024 \\
\hline \multirow[t]{3}{*}{$\mathrm{M} /(\mathrm{CA})_{2}$} & $\mathrm{~N}-\mathrm{H} \cdots \mathrm{N}$ & 0.0446 & 0.0948 & -0.0368 & -0.0065 \\
\hline & $\mathrm{N}-\mathrm{H} \cdots \mathrm{O}$ & 0.0252 & 0.0942 & -0.0188 & 0.0024 \\
\hline & $\mathrm{N}-\mathrm{H} \cdots \mathrm{O}$ & 0.0242 & 0.0905 & -0.0178 & 0.0024 \\
\hline \multirow[t]{3}{*}{$\mathrm{M} /(\mathrm{CA})_{3}$} & $\mathrm{~N}-\mathrm{H} \cdots \mathrm{N}$ & 0.0446 & 0.0948 & -0.0368 & -0.0065 \\
\hline & $\mathrm{N}-\mathrm{H} \cdots \mathrm{O}$ & 0.0252 & 0.0942 & -0.0188 & 0.0024 \\
\hline & $\mathrm{N}-\mathrm{H} \cdots \mathrm{O}$ & 0.0242 & 0.0905 & -0.0178 & 0.0024 \\
\hline \multicolumn{6}{|l|}{ (b) } \\
\hline \multirow[t]{3}{*}{ M/TCA } & $\mathrm{N}-\mathrm{H} \cdots \mathrm{N}$ & 0.0453 & 0.0942 & -0.0374 & -0.0069 \\
\hline & $\mathrm{N}-\mathrm{H} \cdots \mathrm{S}$ & 0.0152 & 0.0401 & -0.0076 & 0.0012 \\
\hline & $\mathrm{N}-\mathrm{H} \cdots \mathrm{S}$ & 0.0151 & 0.0400 & -0.0076 & 0.0012 \\
\hline \multirow[t]{3}{*}{$\mathrm{M} /(\mathrm{TCA})_{2}$} & $\mathrm{~N}-\mathrm{H} \cdots \mathrm{N}$ & 0.0413 & 0.0929 & -0.0329 & -0.0048 \\
\hline & $\mathrm{N}-\mathrm{H} \cdots \mathrm{S}$ & 0.0149 & 0.0396 & -0.0075 & 0.0012 \\
\hline & $\mathrm{N}-\mathrm{H} \cdots \mathrm{S}$ & 0.0158 & 0.0412 & -0.0080 & 0.0012 \\
\hline \multirow[t]{9}{*}{$\mathrm{M} /(\mathrm{TCA})_{3}$} & $\mathrm{~N}-\mathrm{H} \cdots \mathrm{N}$ & 0.0411 & 0.0925 & -0.0326 & -0.0047 \\
\hline & $\mathrm{N}-\mathrm{H} \cdots \mathrm{S}$ & 0.0150 & 0.0396 & -0.0075 & 0.0012 \\
\hline & $\mathrm{N}-\mathrm{H} \cdots \mathrm{S}$ & 0.0152 & 0.0403 & -0.0077 & 0.0012 \\
\hline & $\mathrm{N}-\mathrm{H} \cdots \mathrm{N}$ & 0.0417 & 0.0933 & -0.0334 & -0.0050 \\
\hline & $\mathrm{N}-\mathrm{H} \cdots \mathrm{S}$ & 0.0127 & 0.0349 & -0.0063 & 0.0012 \\
\hline & $\mathrm{N}-\mathrm{H} \cdots \mathrm{S}$ & 0.0157 & 0.0411 & -0.0079 & 0.0012 \\
\hline & $\mathrm{N}-\mathrm{H} \cdots \mathrm{N}$ & 0.0126 & 0.0353 & -0.0058 & 0.0015 \\
\hline & $\mathrm{N}-\mathrm{H} \cdots \mathrm{S}$ & 0.0202 & 0.0514 & -0.0113 & 0.0008 \\
\hline & $\mathrm{N}-\mathrm{H} \cdots \mathrm{S}$ & 0.0202 & 0.0514 & -0.0113 & 0.0008 \\
\hline \multicolumn{6}{|l|}{ (c) } \\
\hline $\mathrm{M} / \mathrm{CACl}$ & $\mathrm{N}-\mathrm{Cl} \cdots \mathrm{N}$ & 0.0327 & 0.1061 & -0.0237 & 0.0014 \\
\hline \multirow[t]{2}{*}{$\mathrm{M} /(\mathrm{CACl})_{2}$} & $\mathrm{~N}-\mathrm{Cl} \cdots \mathrm{N}$ & 0.0306 & 0.1012 & -0.0222 & 0.0016 \\
\hline & $\mathrm{N}-\mathrm{H} \cdots \mathrm{Cl}$ & 0.0077 & 0.0306 & -0.0045 & 0.0016 \\
\hline $\begin{array}{l}\mathrm{M} /(\mathrm{CACl})_{3} \\
\text { (d) }\end{array}$ & $\mathrm{N}-\mathrm{H} \cdots \mathrm{Cl}$ & 0.0297 & 0.0990 & -0.0215 & 0.0016 \\
\hline \multirow[t]{3}{*}{$\mathrm{M} / \mathrm{CABr}$} & $\mathrm{N}-\mathrm{Br} \cdots \mathrm{N}$ & 0.0493 & 0.1233 & -0.0391 & -0.0041 \\
\hline & $\mathrm{N}-\mathrm{H} \cdots \mathrm{Br}$ & 0.0097 & 0.0357 & -0.0055 & 0.0145 \\
\hline & $\mathrm{N}-\mathrm{H} \cdots \mathrm{Br}$ & 0.0097 & 0.0356 & -0.0055 & 0.0144 \\
\hline \multirow[t]{3}{*}{$\mathrm{M} /(\mathrm{CABr})_{2}$} & $\mathrm{~N}-\mathrm{Br} \cdots \mathrm{N}$ & 0.0442 & 0.1181 & -0.0343 & -0.0024 \\
\hline & $\mathrm{N}-\mathrm{H} \cdots \mathrm{Br}$ & 0.0094 & 0.0345 & -0.0053 & 0.0017 \\
\hline & $\mathrm{N}-\mathrm{H} \cdots \mathrm{Br}$ & 0.0092 & 0.0338 & -0.0052 & 0.0016 \\
\hline \multirow[t]{3}{*}{$\mathrm{M} /(\mathrm{CABr})_{3}$} & $\mathrm{~N}-\mathrm{Br} \cdots \mathrm{N}$ & 0.0397 & 0.1112 & -0.0301 & -0.0011 \\
\hline & $\mathrm{N}-\mathrm{H} \cdots \mathrm{Br}$ & 0.0090 & 0.0327 & -0.0050 & 0.0016 \\
\hline & $\mathrm{N}-\mathrm{H} \cdots \mathrm{Br}$ & 0.0089 & 0.0325 & -0.0050 & 0.0016 \\
\hline
\end{tabular}

All quantities are in atomic units (au)

monomer. The sum of densities at these BCP, decreases: $0.0960 \mathrm{au} ; 0.0940 \mathrm{au} ; 0.0925 \mathrm{au}$ in the bimolecular, trimolecular, and tetramolecular complexes, respectively. The same is observed in complexes with sulfur. Considering that it has been established that the density at the BCP is a good indicator of the strength of the bond [50, 55, 56], these results are contrary to what is expected of the cooperative effect of HBs. However, a reinforcement of the outer $\mathrm{N}-\mathrm{H} \cdots \mathrm{O}$ interactions is observed, when going from $\mathrm{M} / \mathrm{CA}$ to $\mathrm{M} /(\mathrm{CA})_{2}$, which is marked by the increase in $\rho\left(\mathrm{r}_{\mathrm{c}}\right)$ values (from 0.0247 to 0.0252 au, see Table 3a). In Fig. 4c it can also be seen that in the complex with chlorine, M/ $\mathrm{CACl}$, a single interaction of the type $\mathrm{N}-\mathrm{Cl} \cdots \mathrm{N}$ is observed. When the trimolecular complex is formed, two interactions of $\mathrm{HB}$ type, $\mathrm{N}-\mathrm{H} \cdots \mathrm{Cl}$, appear and disappear again in the tetramolecular complex. Contrarily, in the system $\mathrm{M} / \mathrm{CABr}$, in addition to $\mathrm{XB}$, two HBs interactions occur, and these persist to pass to tri- and tetramolecular complexes. Also, in these halogenated systems, an anti-cooperative effect is observed.

It is known that the $\mathrm{BE}$ is a magnitude that cannot be partitioned when more than one interaction are involved in the same complex; for this reason, several studies have been accomplished with the purpose of measuring the strength of individual interactions in a binary complex involving more than one interaction [57]. Matta et al. [58] have based their studies on the methodology of Espinosa et al. [55]. This method has stated that for the hydrogen bond $\mathrm{X}-\mathrm{H} \cdots \mathrm{O}$ (where $\mathrm{X}=\mathrm{C}, \mathrm{N}, \mathrm{O}$ ), there is a relationship between bond energy of the $\mathrm{HB}$ (named $E_{\mathrm{HB}}$ ) and the potential energy density $V\left(\mathbf{r}_{\mathrm{c}}\right)$ at the corresponding $\mathrm{BCP}$, which can be approximately described as $E_{\mathrm{HB}}=V\left(\mathbf{r}_{\mathrm{c}}\right) / 2$. Moreover, Reiher et al. [59] correlated the strength of the HB with the two-center shared-electron number [59]. Later on Szatyłowicz et al. [57] employed the NBO energy in order to explore the strengths of interactions in DNA base pairs complexes. In this work, the concept of Espinosa et al. [55] was used in order to evaluate the relationship between $V\left(\mathbf{r}_{\mathrm{c}}\right)$ and the BEs, by considering the sum of the $E_{\mathrm{HB}}$ in each individual interaction of complexes, that is: $\Sigma V\left(\mathbf{r}_{\mathrm{c}}\right) / 2$. Then, these values were plotted versus the BEs of Table 1 (see Fig. S1 in Online Resource). Results show a good linear correlation, as it is evidenced in the value of the correlation coefficients $\left(R^{2}=0.973\right)$, even though this evaluation was limited just to $\mathrm{H} \cdots \mathrm{O}$ bonds. Therefore, this methodology could be considered suitable to quantify the contribution of individual interactions to the total BE.

Finally, according to Cremer and Kraka [60], when $H\left(\mathbf{r}_{\mathrm{c}}\right)$ is negative at a BCP, the interaction is indicative of being shared and its magnitude could be used as a measure of the covalent character. However, Angelina et al. [61, 62] have indicated that the decrease in $H\left(\mathbf{r}_{\mathrm{c}}\right)$ is mainly due to the increase in the electrostatic character of the interaction and in lesser extent to the increase in its covalent character. Therefore, negative values of $\mathrm{H}$ could be considered as an indicator of strengthening or stabilization of the interaction [61]. As can be seen in Table 3a in the set of three interactions, the central interaction $\mathrm{N}-\mathrm{H} \cdots \mathrm{N}$ has a negative value 
Table 4 Changes in atomic properties for three atoms involved in intermolecular interactions of bimolecular complexes

\begin{tabular}{|c|c|c|c|c|c|c|}
\hline Complex & Interaction & Atom & $\Delta N(\Omega)$ & $\Delta E(\Omega)$ & $\Delta v(\Omega)$ & $\Delta M(\Omega)$ \\
\hline \multirow[t]{9}{*}{ M/CA } & \multirow[t]{3}{*}{$\mathrm{N}-\mathrm{H} \cdots \mathrm{N}$} & $\mathrm{N}$ & 0.0551 & -0.0385 & 0.2766 & -0.0256 \\
\hline & & $\mathrm{H}$ & -0.0806 & 0.0610 & -11.7608 & -0.0444 \\
\hline & & $\mathrm{N}$ & 0.0267 & -0.0022 & -14.6366 & -0.0590 \\
\hline & \multirow[t]{3}{*}{$\mathrm{N}-\mathrm{H} \cdots \mathrm{O}$} & $\mathrm{N}$ & 0.0332 & -0.0310 & -0.0585 & 0.0064 \\
\hline & & $\mathrm{H}$ & -0.0565 & 0.0295 & -9.2387 & -0.0376 \\
\hline & & $\mathrm{O}$ & 0.0197 & -0.0007 & -7.2081 & -0.0258 \\
\hline & \multirow[t]{3}{*}{$\mathrm{N}-\mathrm{H} \cdots \mathrm{O}$} & $\mathrm{N}$ & 0.0330 & -0.0310 & -0.1222 & 0.0055 \\
\hline & & $\mathrm{H}$ & -0.0565 & 0.0295 & -9.2323 & -0.0376 \\
\hline & & $\mathrm{O}$ & 0.0196 & -0.0007 & -7.1885 & -0.0258 \\
\hline \multirow[t]{9}{*}{ M/TCA } & \multirow[t]{3}{*}{$\mathrm{N}-\mathrm{H} \cdots \mathrm{N}$} & $\mathrm{N}$ & 0.0423 & -0.0135 & 0.5217 & -0.0309 \\
\hline & & $\mathrm{H}$ & -0.0753 & 0.0570 & -12.6372 & -0.0475 \\
\hline & & $\mathrm{N}$ & 0.0259 & -0.0155 & -15.6212 & -0.0740 \\
\hline & \multirow[t]{3}{*}{$\mathrm{N}-\mathrm{H} \cdots \mathrm{S}$} & $\mathrm{N}$ & -0.0230 & 0.0121 & -1.1994 & 0.0044 \\
\hline & & $\mathrm{H}$ & -0.0025 & 0.0083 & -3.7356 & -0.0060 \\
\hline & & $S$ & 0.0446 & -0.0299 & -7.4819 & -0.0097 \\
\hline & \multirow[t]{3}{*}{$\mathrm{N}-\mathrm{H} \cdots \mathrm{S}$} & $\mathrm{N}$ & -0.0230 & 0.0122 & -1.2098 & 0.0045 \\
\hline & & $\mathrm{H}$ & -0.0025 & 0.0082 & -3.7445 & -0.0059 \\
\hline & & $\mathrm{S}$ & 0.0445 & -0.0298 & -7.4561 & -0.0095 \\
\hline \multirow[t]{3}{*}{$\mathrm{M} / \mathrm{CACl}$} & \multirow[t]{3}{*}{$\mathrm{N}-\mathrm{Cl} \cdots \mathrm{N}$} & $\mathrm{N}$ & 0.0427 & -0.0346 & 1.1134 & -0.0323 \\
\hline & & $\mathrm{Cl}$ & -0.0080 & 0.0076 & -12.9247 & -0.1434 \\
\hline & & $\mathrm{N}$ & -0.0018 & -0.0247 & -19.3408 & -0.1384 \\
\hline \multirow[t]{9}{*}{$\mathrm{M} / \mathrm{CABr}$} & \multirow[t]{3}{*}{$\mathrm{N}-\mathrm{Br} \cdots \mathrm{N}$} & $\mathrm{N}$ & 0.0554 & -0.0450 & 2.8414 & -0.0396 \\
\hline & & $\mathrm{Br}$ & -0.0043 & 0.0153 & -19.8834 & -0.3044 \\
\hline & & $\mathrm{N}$ & 0.0034 & -0.0245 & -24.5173 & -0.1649 \\
\hline & \multirow[t]{3}{*}{$\mathrm{N}-\mathrm{H} \cdots \mathrm{Br}$} & $\mathrm{N}$ & 0.0050 & -0.0110 & -1.3707 & 0.0060 \\
\hline & & $\mathrm{H}$ & -0.0208 & 0.0134 & -2.0542 & -0.0097 \\
\hline & & $\mathrm{Br}$ & -0.0043 & 0.0153 & -19.8834 & -0.3044 \\
\hline & \multirow[t]{3}{*}{$\mathrm{N}-\mathrm{H} \cdots \mathrm{Br}$} & $\mathrm{N}$ & 0.0049 & -0.0111 & -1.4052 & 0.0060 \\
\hline & & $\mathrm{H}$ & -0.0209 & 0.0135 & -2.1383 & -0.0098 \\
\hline & & $\mathrm{Br}$ & -0.0043 & 0.0153 & -19.8834 & -0.3044 \\
\hline
\end{tabular}

All quantities are in au while the side ones are positive, which is also observed in the M/TCA system (see Table $3 b$ ). Regarding the set of complexes with XBs, $H\left(\mathbf{r}_{\mathrm{c}}\right)$ is positive for $\mathrm{N}-\mathrm{Cl} \cdots \mathrm{N}$ interactions (see Table 3c) which would explain why it is the least energetically favored system. In the $\mathrm{M} / \mathrm{CABr}$ set of complexes, Table $3 \mathrm{~d}$, the $H\left(\mathbf{r}_{\mathrm{c}}\right)$ at $\mathrm{N}-\mathrm{Br} \cdots \mathrm{N}$ BCP reaches the least negative value among all complexes studied $(-0.0041 \mathrm{au})$. Furthermore, by comparing $\mathrm{M} /(\mathrm{CA})_{n}$ with $\mathrm{M} /(\mathrm{CABr})_{n}$ systems, the $H\left(\mathbf{r}_{\mathrm{c}}\right)$ property at the central interaction is reduced by around 26 and $73 \%$, respectively, when going from the simple adduct up to the tetramolecular complex, showing that the strength or stability is less affected in the M/CA set of complexes. However, $\rho\left(\mathbf{r}_{\mathrm{c}}\right)$ in the $\mathrm{M} /(\mathrm{CABr})_{n}$ system is greater than in the $\mathrm{M} /(\mathrm{CA})_{n}$ system, indicating stronger interactions in the former. Hence, the greatest BE in the M/CA system is explained by $\rho\left(\mathbf{r}_{\mathrm{c}}\right)$ and $H\left(\mathbf{r}_{\mathrm{c}}\right)$ values.

\subsection{Integrated atomic properties}

In Table 4 changes in the integrated atomic properties for the three atoms involved in the interactions of adducts $\mathrm{M} /$ $\mathrm{CA}, \mathrm{M} / \mathrm{TCA}, \mathrm{M} / \mathrm{CACl}$, and $\mathrm{M} / \mathrm{CABr}$ are shown (data of tri and tetramolecular complexes are given in Table $\mathrm{S} 1$ in the Online Resource). Such properties are the electronic population, $N$, the total energy of the atom, $E$, the dipolar polarization, $M$, and the atomic volume, $v$. The changes were calculated by subtracting the property value of the atom in the isolated compound to the value of the corresponding property in the complex. The criteria for the hydrogen bond formation [44, 63], based on the integrated properties of the hydrogen atom, involve loss of electron population $(\Delta N<0)$, energetic destabilization $(\Delta E>0)$, decrease in dipolar polarization $(\Delta M<0)$, and decrease in hydrogen atoms volume $(\Delta V<0)$. 
As can be seen in Table 4, these criteria are satisfied for the hydrogen-bonded adducts (M/CA and M/TCA). In addition, on the other two atoms involved in the HBs, $\mathrm{A}$ and $\mathrm{D}$ atoms, the atomic volume decreased on the $\mathrm{A}$ atom and increased on the $\mathrm{D}$ atom for the M/CA dimer. Whereas this behavior is observed just in the central interaction in the M/TCA dimer, in the side ones a decrease in the atomic volumes is evidenced in the three atoms involved D-H...A.

In halogen complexes, $\mathrm{M} / \mathrm{CACl}$ and $\mathrm{M} / \mathrm{CABr}$, the general trend in the $\mathrm{XB}$ donor is a loss of electron population, a decrease in the dipolar polarization, a decrease in the atomic volume, and an energetic destabilization, in contrast with values reported for halogen bonds [52]. However, this trend agrees with values reported for $\mathrm{I} \cdots \mathrm{N}$ interactions [53]. The energetic destabilization is greater in the chlorinated complex, which is in line with the lowest value of $\mathrm{BE}$. On the other hand, the $\mathrm{XB}$ acceptor (nitrogen atom) shows a loss of $N(\Omega)$ in $\mathrm{M} / \mathrm{CACl}$ complex, while in the $\mathrm{M} / \mathrm{CABr}$ complex the $\mathrm{XB}$ acceptor shows a gain of electron population $(\Delta N>0)$.

\subsection{Natural bond orbital (NBO) analysis}

The results of NBO analysis conducted on clusters are given in Table 5a-d. The values reported in this table are the changes in NBO occupation numbers for the $\sigma_{\mathrm{D}-\mathrm{X}}^{*}$ antibonds and $n_{\mathrm{A}}$ lone pairs (LP) of $\mathrm{D}-\mathrm{X} \cdots \mathrm{A}$ interactions upon complexation, that is, the difference between the values in the complex and in the isolated molecules. Additionally, the second-order perturbation energies $E^{(2)}$ (donor $\rightarrow$ acceptor) are reported.

An analysis of the results in Table 5 shows that the hyperconjugative energy of charge transfer follows the same order as the binding energies. Moreover, they correlate fairly well with the electron density values at BCP of the corresponding interactions. Besides, there is an acceptable correlation between the binding energies and the sum of the $E^{(2)}$ energies at each complex $\left(R^{2}=0.938\right.$, see Fig. $\mathrm{S} 2$ in Online Resources). Therefore, these results also support the idea proposed by Szatyłowicz and Sadlej-Sosnowska [57] based on NBO energies.

It is important to note that upon complex formation, all anti-bonds increase their occupation number, as indicated by positive values of $\Delta \sigma^{*}$, which range from 0.007 to 0.2 $\mathrm{e}$ in halogen complexes, and from 0.01 to $0.09 \mathrm{e}$ in hydrogen complexes. Moreover, as reflected in the $\Delta n$ values, all LP lost occupation number as it is expected, except LPs of oxygen atoms in the M/CA system (see Table 5a), which gain occupation number even though there is a charge outflow, as it is evidenced from the charge transfer values. This unusual behavior is explained by analyzing the intramolecular charge transfers.
Table 5 Changes in NBO populations of lone pairs $\left(n_{\mathrm{A}}\right)$ and antibonds $\left(\sigma_{\mathrm{D}-\mathrm{X}}^{*}\right)$ from (a) $\mathrm{M} /(\mathrm{CA})_{n}$, (b) $\mathrm{M} /(\mathrm{TCA})_{n}$, (c) $\mathrm{M} /(\mathrm{CACl})_{n}$, (d) $\mathrm{M} /(\mathrm{CABr})_{n}$ complexes and second-order perturbation energies $E^{(2)}$ $\left(n_{\mathrm{A}} \rightarrow \sigma_{\mathrm{D}-\mathrm{X}}^{*}\right)$

\begin{tabular}{|c|c|c|c|c|}
\hline Complex & $\mathrm{D}-\mathrm{X} \cdots \mathrm{A}$ & $\Delta n$ & $E^{(2)}$ & $\Delta \sigma^{*}$ \\
\hline \multicolumn{5}{|l|}{ (a) } \\
\hline \multirow[t]{3}{*}{$\mathrm{M} / \mathrm{CA}$} & $\mathrm{N}-\mathrm{H} \cdots \mathrm{N}$ & -0.0550 & 41.13 & 0.0808 \\
\hline & $\mathrm{N}-\mathrm{H} \cdots \mathrm{O}$ & 0.0079 & 7.76 & 0.0199 \\
\hline & $\mathrm{N}-\mathrm{H} \cdots \mathrm{O}$ & 0.0079 & 7.76 & 0.0199 \\
\hline \multirow[t]{3}{*}{$\mathrm{M} /(\mathrm{CA})_{2}$} & $\mathrm{~N}-\mathrm{H} \cdots \mathrm{N}$ & -0.0526 & 38.65 & 0.0766 \\
\hline & $\mathrm{N}-\mathrm{H} \cdots \mathrm{O}$ & 0.0076 & 8.11 & 0.0207 \\
\hline & $\mathrm{N}-\mathrm{H} \cdots \mathrm{O}$ & 0.0066 & 7.62 & 0.0198 \\
\hline \multirow[t]{3}{*}{$\mathrm{M} /(\mathrm{CA})_{3}$} & $\mathrm{~N}-\mathrm{H} \cdots \mathrm{N}$ & -0.0510 & 36.74 & 0.0734 \\
\hline & $\mathrm{N}-\mathrm{H} \cdots \mathrm{O}$ & 0.0064 & 8.02 & 0.0207 \\
\hline & $\mathrm{N}-\mathrm{H} \cdots \mathrm{O}$ & 0.0064 & 8.00 & 0.0207 \\
\hline \multicolumn{5}{|l|}{ (b) } \\
\hline \multirow[t]{3}{*}{ M/TCA } & $\mathrm{N}-\mathrm{H} \cdots \mathrm{N}$ & -0.0559 & 41.22 & 0.0804 \\
\hline & $\mathrm{N}-\mathrm{H} \cdots \mathrm{S}$ & -0.0004 & 4.46 & 0.0200 \\
\hline & $\mathrm{N}-\mathrm{H} \cdots \mathrm{S}$ & -0.0004 & 4.44 & 0.0200 \\
\hline \multirow[t]{3}{*}{$\mathrm{M} /(\mathrm{TCA})_{2}$} & $\mathrm{~N}-\mathrm{H} \cdots \mathrm{N}$ & -0.0503 & 36.34 & 0.0721 \\
\hline & $\mathrm{N}-\mathrm{H} \cdots \mathrm{S}$ & -0.0017 & 5.03 & 0.0222 \\
\hline & $\mathrm{N}-\mathrm{H} \cdots \mathrm{S}$ & -0.0020 & 4.28 & 0.0193 \\
\hline \multirow[t]{9}{*}{$\mathrm{M} /(\mathrm{TCA})_{3}$} & $\mathrm{~N}-\mathrm{H} \cdots \mathrm{N}$ & -0.0512 & 36.16 & 0.0721 \\
\hline & $\mathrm{N}-\mathrm{H} \cdots \mathrm{S}$ & -0.0019 & 4.59 & 0.0212 \\
\hline & $\mathrm{N}-\mathrm{H} \cdots \mathrm{S}$ & -0.0018 & 4.13 & 0.0192 \\
\hline & $\mathrm{N}-\mathrm{H} \cdots \mathrm{N}$ & -0.0518 & 36.57 & 0.0729 \\
\hline & $\mathrm{N}-\mathrm{H} \cdots \mathrm{S}$ & -0.0025 & 5.1 & 0.0232 \\
\hline & $\mathrm{N}-\mathrm{H} \cdots \mathrm{S}$ & 0.0004 & 2.56 & 0.0132 \\
\hline & $\mathrm{N}-\mathrm{H} \cdots \mathrm{N}$ & -0.0111 & 7.02 & 0.0190 \\
\hline & $\mathrm{N}-\mathrm{H} \cdots \mathrm{S}$ & -0.0139 & 12.61 & 0.0336 \\
\hline & $\mathrm{N}-\mathrm{H} \cdots \mathrm{S}$ & -0.0139 & 12.63 & 0.0336 \\
\hline \multicolumn{5}{|l|}{ (c) } \\
\hline $\mathrm{M} / \mathrm{CACl}$ & $\mathrm{N}-\mathrm{Cl} \cdots \mathrm{N}$ & -0.0630 & 19.14 & 0.0745 \\
\hline $\mathrm{M} /(\mathrm{CACl})_{2}$ & $\mathrm{~N}-\mathrm{Cl} \cdots \mathrm{N}$ & -0.0565 & 17.02 & 0.0663 \\
\hline $\begin{array}{l}\mathrm{M} /(\mathrm{CACl})_{3} \\
\text { (d) }\end{array}$ & $\mathrm{N}-\mathrm{Cl} \cdots \mathrm{N}$ & -0.0535 & 16.03 & 0.0621 \\
\hline \multirow[t]{3}{*}{$\mathrm{M} / \mathrm{CABr}$} & $\mathrm{N}-\mathrm{Br} \cdots \mathrm{N}$ & -0.1284 & 47.36 & 0.1508 \\
\hline & $\mathrm{N}-\mathrm{H} \cdots \mathrm{Br}$ & -0.0056 & 1.31 & 0.0020 \\
\hline & $\mathrm{N}-\mathrm{H} \cdots \mathrm{Br}$ & & 1.3 & 0.0020 \\
\hline \multirow[t]{3}{*}{$\mathrm{M} /(\mathrm{CABr})_{2}$} & $\mathrm{~N}-\mathrm{Br} \cdots \mathrm{N}$ & -0.1081 & 38.99 & 0.1265 \\
\hline & $\mathrm{N}-\mathrm{H} \cdots \mathrm{Br}$ & -0.0063 & 1.33 & 0.0021 \\
\hline & $\mathrm{N}-\mathrm{H} \cdots \mathrm{Br}$ & & 1.28 & 0.0017 \\
\hline \multirow[t]{3}{*}{$\mathrm{M} /(\mathrm{CABr})_{3}$} & $\mathrm{~N}-\mathrm{Br} \cdots \mathrm{N}$ & -0.0925 & 32.46 & 0.1075 \\
\hline & $\mathrm{N}-\mathrm{H} \cdots \mathrm{Br}$ & -0.0067 & 1.30 & 0.0018 \\
\hline & $\mathrm{N}-\mathrm{H} \cdots \mathrm{Br}$ & & 1.29 & 0.0018 \\
\hline
\end{tabular}

Occupation numbers in e and energies in $\mathrm{kcal} / \mathrm{mol}$

It is also worth mentioning correlations of $\Delta n$ versus $\Delta \sigma^{*}$ values. By correlating these values from $\mathrm{M} /(\mathrm{CA})_{n} \mathrm{M} /$ $(\mathrm{TCA})_{n}, \mathrm{M} /(\mathrm{CACl})_{n}$, and $\mathrm{M} /(\mathrm{CABr})_{n}$ systems, good linear relationships are observed (plots not shown), with 
$R^{2}=0.9986,0.9804,0.9988$ and 0.9999 respectively (see Fig. S3 in Online Resources). These results show that all of the charge that the donor orbital lost was consequently gained by the acceptor orbital. However, as was aforementioned, LPs of oxygen atoms in the M/CA system gain occupation number. Despite the fact that oxygen atoms of CA act as donors, they also act as acceptors in the intramolecular charge transfer $\Delta n_{\mathrm{N}} \rightarrow \Delta \sigma_{\mathrm{C}=\mathrm{O}}^{*}$ (see Fig. 5b), that is, six $\Delta n_{\mathrm{N}} \rightarrow \Delta \sigma_{\mathrm{C}=\mathrm{O}}^{*}$ CTs which increase in energy upon complex formation (see Table 6). Therefore, it may be suspected that the gain of occupation number of oxygen LP comes from this transfer, which is the most relevant one within the CA molecule. Consequently, intermolecular charge transfers improve the intramolecular ones and the net charge flow (Fig. 5c) resulting in a "closed circuit", which is the result of the sum of the intra- and intermolecular charge transfers. Despite the fact that values of BEs show
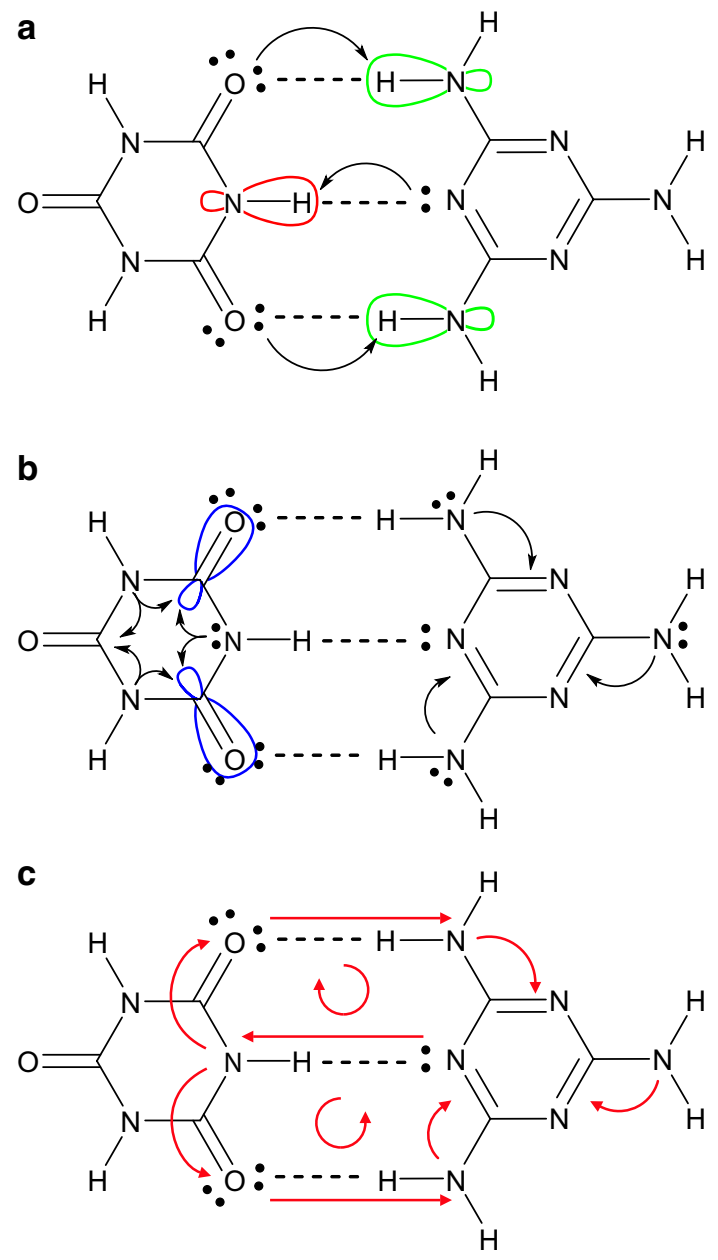

Fig. 5 a Schematic representation of $n \rightarrow \sigma^{*}$ intermolecular charge transfers involving interactions in $\mathrm{M} / \mathrm{CA}$ adduct. b Schematic representation $n \rightarrow \sigma^{*}$ of intramolecular charge transfers within $\mathrm{M}$ $\left(n_{N} \rightarrow \sigma_{\mathrm{C}-\mathrm{N}}^{*}\right)$ and CA $\left(n_{N} \rightarrow \sigma_{\mathrm{C}=\mathrm{O}}^{*}\right)$. c Charge delocalization mechanism that defines the interaction between $\mathrm{M}$ and $\mathrm{CA}$
Table 6 NBO analysis of M, CA, and M/CA complex: second-order perturbation energies $E^{(2)}$ (donor $\rightarrow$ acceptor)

\begin{tabular}{|c|c|c|c|}
\hline & M & CA & $\mathrm{M} / \mathrm{CA}$ \\
\hline \multicolumn{4}{|c|}{ Intramolecular } \\
\hline$n_{\mathrm{N}} \rightarrow \sigma_{\mathrm{C}=\mathrm{O}}^{*}$ & & 70.11 & 81.94 \\
\hline \multicolumn{4}{|l|}{$n_{\mathrm{N}} \rightarrow \sigma_{\mathrm{C}=\mathrm{O}}^{*}$} \\
\hline$n_{\mathrm{N}} \rightarrow \sigma_{\mathrm{C}=\mathrm{O}}^{*}$ & & & 72.61 \\
\hline \multicolumn{4}{|l|}{$n_{\mathrm{N}} \rightarrow \sigma_{\mathrm{C}=\mathrm{O}}^{*}$} \\
\hline$n_{\mathrm{N}} \rightarrow \sigma_{\mathrm{C}=\mathrm{O}}^{*}$ & & & 70.28 \\
\hline \multicolumn{4}{|l|}{$n_{\mathrm{N}} \rightarrow \sigma_{\mathrm{C}=\mathrm{O}}^{*}$} \\
\hline$n_{\mathrm{N}} \rightarrow \sigma_{\mathrm{C}-\mathrm{N}}^{*}$ & 75.78 & & 91.35 \\
\hline$n_{\mathrm{N}} \rightarrow \sigma_{\mathrm{C}-\mathrm{N}}^{*}$ & & & 87.55 \\
\hline$n_{\mathrm{N}} \rightarrow \sigma_{\mathrm{C}-\mathrm{N}}^{*}$ & & & 78.71 \\
\hline \multicolumn{4}{|c|}{ Intermolecular } \\
\hline$n_{\mathrm{N}} \rightarrow \sigma_{\mathrm{N}-\mathrm{H}}^{*}$ & & & 41.13 \\
\hline$n_{\mathrm{O}} \rightarrow \sigma_{\mathrm{N}-\mathrm{H}}^{*}$ & & & 7.76 \\
\hline$n_{\mathrm{O}} \rightarrow \sigma_{\mathrm{N}-\mathrm{H}}^{*}$ & & & 7.76 \\
\hline
\end{tabular}

Energies in $\mathrm{kcal} / \mathrm{mol}$

an anti-cooperative effect, this charge delocalization mechanism is cooperative, since there is reinforcement over intramolecular charge transfers upon complexation (see Table 6). Furthermore, in the complexes that do not present the side $\mathrm{N}-\mathrm{H} \cdots \mathrm{O}$ interactions, that is the systems: $\mathrm{M} /(\mathrm{CACl})_{n}$ and $\mathrm{M} /(\mathrm{CABr})_{n}$, oxygen atoms still exhibit an increase in the occupation numbers of $n_{\mathrm{O}} \mathrm{LP}\left(\Delta n_{\mathrm{O}}=0.0081 \mathrm{e}\right.$ in $\mathrm{M} /$ $(\mathrm{CACl})_{n}$, and $\Delta n_{\mathrm{O}}=0.013 \mathrm{e}$ in $\left.\mathrm{M} /(\mathrm{CABr})_{n}\right)$.

\subsection{Aromaticity indices}

Aromaticity is a fundamental concept of organic chemistry and can give valuable information about the electronic structure of organic compounds [64]. In this way, aromatic indices are suitable for the study of changes in aromaticity due to the intermolecular perturbations like hydrogen bonds $[64,65]$. This approach was employed in this work as a measure of the intermolecular perturbation over the ring of $\mathrm{M}$ in the different complexes.

Figure 6 shows a display of the aromaticity indices as a function of the monomers added over M. The aromaticity descriptors are shown in Fig. 7. In all cases it can be seen that the aromatic character decreases upon complexes formation. Since there is not a certain method for quantifying the aromatic character of molecules, it cannot be clearly said in which of all systems the aromatic character is more affected. In other words, results show the multidimensional character of aromatic indices. However, correlations of all indices are quite good (cf. Table S2 in electronic supplementary material), although some correlations of indices of $\mathrm{CABr}$ systems do not show a good linear relationship, considering significant Pearson coefficient values of $<0.05$. 

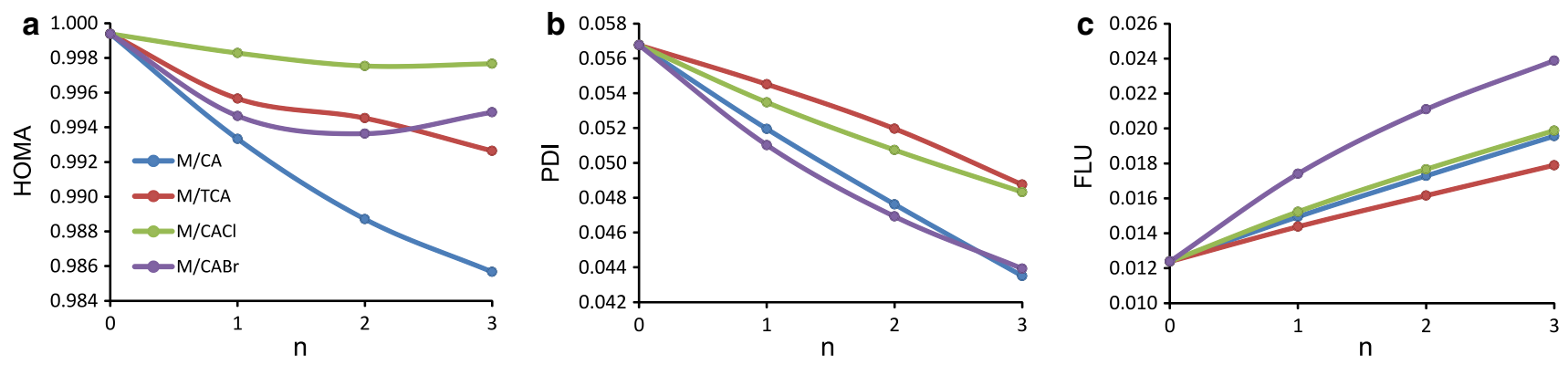

Fig. 6 Aromatic indices of $\mathrm{M}$ ring as a function of the monomers around it
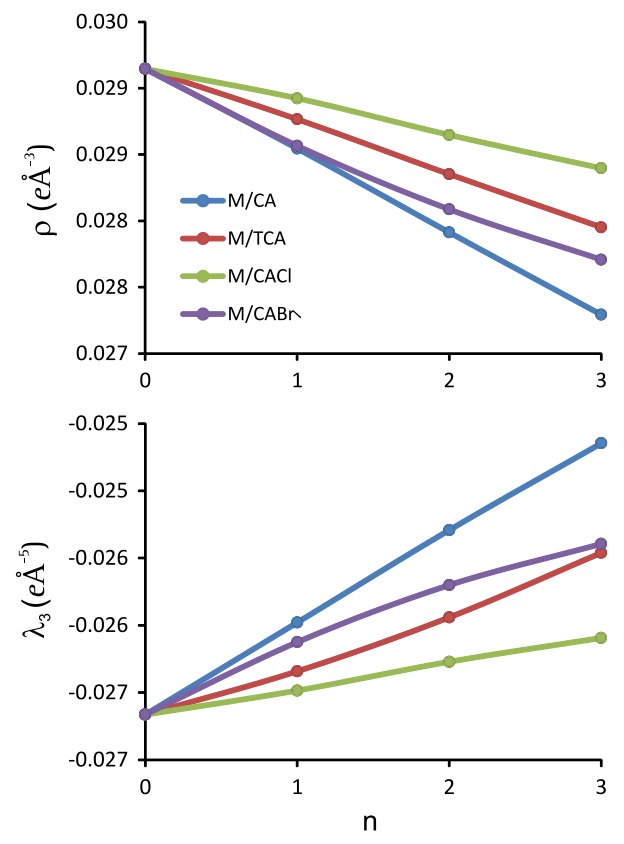

Fig. 7 Aromaticity descriptors of $\mathrm{M}$ ring as a function of the monomers around it

By following the rate of change of indices, according to HOMA, the aromaticity of $\mathrm{M}$ in the system $\mathrm{M} /(\mathrm{CA})_{n}$ is the most affected (see Fig. 6a); the greater the slope, the greater the change of the aromatic character. According to PDI index (Fig. 6b), $\mathrm{M}$ is more affected in the $\mathrm{M} /(\mathrm{CABr})_{n}$ system and below it is the $\mathrm{M} /(\mathrm{CA})_{n}$ system. By analyzing FLU indices (see Fig. 6c), it is shown again that the $\mathrm{M}$ aromatic character is more affected in the $\mathrm{M} /(\mathrm{CABr})_{n}$ system. Also, charge density descriptors $\lambda_{3}$ and $\rho_{(\mathrm{RCP})}$ of Fig. $7 \mathrm{a}, \mathrm{b}$ show that $\mathrm{M}$ aromatic character decreases to a greater extent in the $\mathrm{M} /(\mathrm{CA})_{n}$ and $\mathrm{M} /(\mathrm{CABr})_{n}$ systems. Thus, we can conclude that $\mathrm{M}$ aromatic character is more perturbed in the $\mathrm{M} /(\mathrm{CA})_{n}$ and $\mathrm{M} /(\mathrm{CABr})_{n}$ systems and less affected in the $\mathrm{M} /(\mathrm{CACl})_{n}$ and $\mathrm{M} /(\mathrm{TCA})_{n}$ systems, but it is not possible to determine a unique trend.
This classification is consistent with the strength of the interactions.

\section{Conclusions}

In this work, a structural and an electronic analyses at $\omega-\mathrm{B} 97 \mathrm{XD} / 6-311++\mathrm{G}^{* *}$ level of theory were carried out on a series of supramolecular complexes formed by hydrogen and halogen bonds. The AIM theory in conjunction with NBO analysis and a set of aromaticity descriptors were also applied to understand the molecular factors that govern the self-assembly of the compounds studied. Quantitative insights into the electronic structure of $\mathrm{M}$ and molecular interactions involved in the self-assembly of this compound were gained. The most important fact is that an anti-cooperative effect is observed in all complexes, against the expected behavior and the general assumption in supramolecular assemblies via hydrogen bonds.

From the QTAIM analysis, as well as the NBO analysis, it is observed that the strongest interactions are those in the $\mathrm{M} /(\mathrm{CA})_{n}$ for hydrogen-bonded complexes and in the $\mathrm{M} /(\mathrm{CABr})_{n}$ systems for halogen-bonded complexes. These results may be helpful for the future experimental design of new materials, since the design of materials based on halogen bonds is still at an early-stage research.

It could also be seen that TCA molecule is not suitable to form planar structures, despite the fact that the crystalline structure of M/TCA is geometrically the same as M/ CA co-crystal.

On the other hand, the complexation of $\mathrm{M}$ leads to a great decrease in its aromatic character due to the intermolecular interactions. It can be concluded that the decrease in the aromaticity is higher in complexes in which interactions are stronger, that is in the $\mathrm{M} /(\mathrm{CA})_{n}$ and $\mathrm{M} /(\mathrm{CABr})_{n}$ systems.

Acknowledgments We would like to thank SECYT UTN (Secretaría de Ciencia y Tecnología - Universidad Tecnológica Nacional), 
for financial support. A.N.P. is a fellowship researcher of CONICET, Argentina (Consejo Nacional de Investigaciones Científicas y Técnicas), and N.M.P. is a career researcher of CONICET, Argentina.

\section{References}

1. Lehn J-M (1988) Supramolecular chemistry-scope and perspectives molecules, supermolecules, and molecular devices (Nobel Lecture). Angew Chemie Int Ed Engl 27:89-112. doi:10.1002/ anie. 198800891

2. Atwood JL, Steed JW (2004) Encyclopedia of supramolecular chemistry, vol 1. CRC Press, New York, Besel

3. Lehn J-M (1973) Design of organic complexing agents strategies towards properties. Struct Bond 16:1-69

4. Lehn JM (1978) Cryptates: inclusion complexes of macropolycyclic receptor molecules. Pure Appl Chem 50:871-892. doi:10.1351/pac197850090871

5. Lehn J-M (2002) Toward complex matter: supramolecular chemistry and self-organization. Proc Natl Acad Sci USA 99:47634768. doi:10.1073/pnas.072065599

6. Wyler R, de Mendoza J, Rebek J (1993) A synthetic cavity assembles through self-complementary hydrogen bonds. Angew Chem Int Ed Engl 32:1699-1701. doi:10.1002/anie.199316991

7. Seto CT, Whitesides GM (1993) Molecular self-assembly through hydrogen bonding: supramolecular aggregates based on the cyanuric acid-melamine lattice. J Am Chem Soc 115:905-916

8. Wang K, Duan D, Zhou M, Li S, Cui T, Liu B, Liu J, Zou B, Zou G (2011) Structural properties and halogen bonds of cyanuric chloride under high pressure. J Phys Chem B 115:4639-4644. doi:10.1021/jp200966n

9. Shang J, Wang Y, Chen M, Dai J, Zhou X, Kuttner J, Hilt G, Shao X, Gottfried JM, Wu K (2015) Assembling molecular Sierpiński triangle fractals. Nat Chem. doi:10.1038/nchem.2211

10. Dey R, Bhattacharya B, Mondal P, Mondal R, Ghoshal D (2014) Fabrication of two supramolecular self-assemblies of $\mathrm{Mn}$ (II)-dicarboxylates with trans-4,4'-azobispyridine: analysis of H-bonding interactions with Hirshfeld surfaces and DFT calculations. J Mol Struct 1067:64-73. doi:10.1016/j. molstruc.2014.02.059

11. Yurenko YP, Novotný J, Mitoraj MP, Sklenár V, Michalak A, Merek R (2014) Nucleic acid quadruplexes based on 8-Halo9-deazaxanthines: energetics and noncovalent interactions in quadruplex stems. J Chem Theory Comput 10:5353-5365

12. Lindsey JS (1991) Self-assembly in sinthetic routes to molecular devices. Biological principles and chemical perspectives: a review. New J Chem 15:153-180

13. Stupp SI, Palmer LC (2014) Supramolecular chemistry and selfassembly in organic materials design. Chem Mater 26:507-518

14. Ariga K, Hill JP, Lee MV, Vinu A, Charvet R, Acharya S (2008) Challenges and breakthroughs in recent research on self-assembly. Sci Technol Adv Mater 9:014109. doi:10.1088/1468-6996/9/1/014109

15. Paraschiv V, Crego-Calama M, Fokkens RH, Padberg CJ, Timmerman P, Reinhoudt DN (2001) Nanostructures via noncovalent synthesis: 144 hydrogen bonds bring together 27 components. J Org Chem 66:8297-8301. doi:10.1021/jo0105742

16. Yagai S, Nakajima T, Karatsu T, Saitow K, Kitamura A (2004) Phototriggered self-assembly of hydrogen-bonded rosette. J Am Chem Soc 126:11500-11508. doi:10.1021/ja047783z

17. Hughes EW (1941) The crystal structure of melamine. J Am Chem Soc 63:1737-1752. doi:10.1021/ja01851a069

18. Dewar MJS, Paoloni L (1957) The electronic structure of melamine. Trans Faraday Soc 53:261-271
19. Meier RJ, Coussens B (1990) The molecular structure of hydrazine and melamine: rotational barriers and hybridisation. J Mol Struct THEOCHEM 209:303-312. doi:10.1016/0166-1280(90)80084-2

20. Wang Y, Pittman CU, Saebo S (1993) Investigation of the structure and properties of ammeline, melamine, and 2,4-diamino-1,3,5-triazine by ab initio calculations. J Org Chem 58:3085-3090. doi:10.1021/jo00063a030

21. Li Z, Chen G, Xu Y, Wang X, Wang Z (2013) Study of the structural and the spectral characteristics of $\left[\mathrm{C}_{3} \mathrm{~N}_{3}\left(\mathrm{NH}_{2}\right)_{3}\right]_{n}(n=1-4)$ clusters. J Phys Chem A 117:12511-12518

22. Silly F, Shaw AQ, Castell MR, Briggs GAD, Mura M, Martsinovich N, Kantorovich L (2008) Melamine structures on the $\mathrm{Au}(111)$ surface. J Phys Chem C 112:11476-11480. doi:10.1021/jp8033769

23. Chiş V, Mile G, Ştiufiuc R, Leopold N, Oltean M (2009) Vibrational and electronic structure of PTCDI and melaminePTCDI complexes. J Mol Struct 924-926:47-53. doi:10.1016/j. molstruc.2008.12.038

24. Atalay Y, Avcı D, Başoğlu A, Okur İ (2005) Molecular structure and vibrational spectra of melamine diborate by density functional theory and ab initio Hartree-Fock calculations. J Mol Struct THEOCHEM 713:21-26. doi:10.1016/j. theochem.2004.09.044

25. Thomas R, Kulkarni GU (2007) A hydrogen-bonded channel structure formed by a complex of uracil and melamine. Beilstein J Org Chem 3:17. doi:10.1186/1860-5397-3-17

26. Makowski SJ, Lacher M, Lermer C, Schnick W (2012) Supramolecular hydrogen-bonded structures between melamine and N-heterocycles. J Mol Struct 1013:19-25. doi:10.1016/j. molstruc.2012.01.010

27. Xu J, Wu G, Wang Z, Zhang X (2012) Generation of 2D organic microsheets from protonated melamine derivatives: suppression of the self assembly of a particular dimension by introduction of alkyl chains. Chem Sci 3:3227. doi:10.1039/c2sc20871g

28. Prior TJ, Armstrong JA, Benoit DM, Marshall KL (2013) The structure of the melamine-cyanuric acid co-crystal. CrystEngComm 15:5838. doi:10.1039/c3ce40709h

29. Wang Y, Wei B, Wang Q (1990) Crystal structure of melamine cyanuric acid complex (1:1) trihydrochloride, MCA.3HCl. J Crystallogr Spectrose Res 20:79-84

30. Li S, Sun L, Chung Y, Weber SG (1999) Artificial receptorfacilitated solid-phase microextraction of arbiturates. Anal Chem 71:2146-2151. doi:10.1021/ac980587o

31. Bader RWF (1990) Atoms in molecules: a quantum theory. Clarendon Press, Oxford

32. Krygowski TM (1993) Crystallographic studies of inter- and intramolecular interactions reflected in aromatic character of. pi.electron systems. J Chem Inf Comput Sci 33:70-78

33. Krygowski TM, Cyranski MK (2001) Structural aspects of aromaticity. Chem Rev 101:1385-1419

34. Poater J, Fradera X, Duran M, Solà M (2003) The delocalization index as an electronic aromaticity criterion: application to a series of planar polycyclic aromatic hydrocarbons. Chem Eur J 9:400-406

35. Matito MD, Solà M (2005) The aromatic fluctuation index (FLU): a new aromaticity index based on electron delocalization. J Chem Phys 122:014109

36. Howard ST, Krygowski TM (1997) Benzenoid hydrocarbon aromaticity in terms of charge density descriptors. Can J Chem 75:1174-1181

37. Frisch MJ, Trucks GW, Schlegel HB, Scuseria GE, Robb MA, Cheeseman JR, Montgomery JA Jr, Vreven T, Kudin KN, Burant JC, Millam JM, Iyengar SS, Tomasi J, Barone V, Mennucci B, Cossi M, Scalmani G, Rega N, Petersson GA, Nakatsuji H, Hada M, Ehara M, Toyota K, Fukuda R, Hasegawa J, 
Ishida M, Nakajima T, Honda Y, Kitao O, Nakai H, Klene M, Li X, Knox JE, Hratchian HP, Cross JB, Bakken V, Adamo C, Jaramillo J, Gomperts R, Stratmann RE, Yazyev O, Austin AJ, Cammi R, Pomelli C, Ochterski JW, Ayala PY, Morokuma K, Voth GA, Salvador P, Dannenberg JJ, Zakrzewski VG, Dapprich S, Daniels AD, Strain MC, Farkas O, Malick DK, Rabuck AD, Raghavachari K, Foresman JB, Ortiz JV, Cui Q, Baboul AG, Clifford S, Cioslowski J, Stefanov BB, Liu G, Liashenko A, Piskorz P, Komaromi I, Martin RL, Fox DJ, Keith T, Al-Laham MA, Peng CY, Nanayakkara A, Challacombe M, Gill PMW, Johnson B, Chen W, Wong MW, Gonzalez C, and Pople JA (2004) Gaussian 03, Revision D.01. Gaussian, Inc., Wallingford CT

38. Chai J-D, Head-Gordon M (2008) Long-range corrected hybrid density functionals with damped atom-atom dispersion corrections. Phys Chem Chem Phys 10:6615-6620

39. Kozuch S, Martin JML (2013) Halogen bonds: benchmarks and theoretical analysis. J Chem Theory Comput 9:1918-1931. doi:10.1021/ct301064t

40. Boys SF, Bernardi F (1970) The calculation of small molecular interactions by the differences of separate total energies. Some procedures with reduced errors. Mol Phys 19:553-559

41. AIMAll Version 12.06.03, Todd A. Keith, TK Gristmill Software, Overland Park KS, USA, 2012 aim.tkgristmill.com

42. Glendening ED, Reed AE, Carpenter JE, Weinhold F NBO Version 3.1

43. Lu T, Chen F (2012) Multiwfn: a multifunctional wavefunction analyzer. J Comp Chem 33:580-592

44. Bondi A (1964) van der Waals volumes and radii. J Phys Chem 68:441-451

45. Song HJ, Xiao HM, Dong HS, Zhu WH (2006) Cooperative effects and strengths of hydrogen bonds in open-chain cis-triaziridine clusters $(\mathrm{n}=2-8)$ : a DFT investigation. J Phys Chem A 110:2225-2230. doi:10.1021/jp055385s

46. Znamenskiy VS, Green ME (2007) Quantum calculations on hydrogen bonds in certain water clusters show cooperative effects. J Chem Theory Comput 3:103-114. doi:10.1055/s-0029-1237430.Imprinting

47. Jalili S, Aghdastinat H (2008) Study of hydrogen bonding in dihydroxyacetone and glyceraldehyde using computational methods. J Mol Struct THEOCHEM 857:7-12. doi:10.1016/j. theochem.2008.01.026

48. Grabowski SJ, Bilewicz E (2006) Cooperativity halogen bonding effect- $\mathrm{Ab}$ initio calculations on $\mathrm{H}_{2} \mathrm{CO} \cdots(\mathrm{ClF})_{n}$ complexes. Chem Phys Lett 427:51-55. doi:10.1016/j.cplett.2006.06.060

49. Ranganathan A, Pedireddi VR, Rao CNR (1999) Hydrothermal synthesis of organic channel structures: 1:1 hydrogen-bonded adducts of melamine with cyanuric and trithiocyanuric acids. J Am Chem Soc 121:1752-1753

50. Carroll MT, Bader RFW (1988) An analysis of the hydrogen bond in BASE-HF complexes using the theory of atoms in molecules. Mol Phys 65:695-722

51. Koch U, Popelier PLA (1995) Characterization of $\mathrm{C}-\mathrm{H}-\mathrm{O}$ hydrogen bonds on the basis of the charge density. J Phys Chem 99:9747-9754. doi:10.1021/j100024a016
52. Amezaga NJM, Pamies SC, Peruchena NM, Sosa GL (2010) Halogen bonding: a study based on the electronic charge density. J Phys Chem A 114:552-562. doi:10.1021/jp907550k

53. Han N, Zeng Y, Sun C, Li X, Sun Z, Meng L (2014) N ‥I halogen bonding interactions: in fluence of lewis bases on their strength and characters. J Phys Chem A 118:7058-7065

54. Duarte DJR, Sosa GL, Peruchena NM (2013) Nature of halogen bonding. A study based on the topological analysis of the Laplacian of the electron charge density and an energy decomposition analysis. J Mol Model 19:2035-2041. doi:10.1007/ s00894-012-1624-8

55. Espinosa E, Molins E, Lecomte C (1998) Hydrogen bond strengths revealed by topological analyses of experimentally observed electron densities. Chem Phys Lett 285:170-173

56. Grabowski SJ (2001) Ab initio calculations on conventional and unconventional hydrogen bonds study of the hydrogen bond strength. J Phys Chem A 105:10739-10746

57. Szatyłowicz H, Sadlej-Sosnowska N (2010) Characterizing the strength of individual hydrogen bonds in DNA base pairs. $\mathrm{J}$ Chem Inf Model 50:2151-2161. doi:10.1021/ci100288h

58. Matta CF, Castillo N, Boyd RJ (2006) Extended weak bonding interactions in DNA: $\pi$-stacking (base-base), base-backbone, and backbone-backbone interactions. J Phys Chem B 110:563-578

59. Reiher M, Sellmann D, Hess BA (2001) Stabilization of diazene in $\mathrm{Fe}$ (II)-sulfur model complexes relevant for nitrogenase activity. I. A new approach to the evaluation of intramolecular hydrogen bond energies. Theor Chem Acc 106:379-392

60. Cremer D, Kraka E (1984) Chemical bonds without bonding electron density - does the difference electron-density analysis suffice for a description of the chemical bond? Angew Chem 23:627-628

61. Angelina EL, Duarte DJR, Peruchena NM (2013) Is the decrease of the total electron energy density a covalence indicator in hydrogen and halogen bonds? J Mol Model 19:2097-2106. doi:10.1007/s00894-012-1674-y

62. Angelina EL, Peruchena NM (2011) Strength and nature of hydrogen bonding interactions in mono- and di-hydrated formamide complexes. J Phys Chem A 115:4701-4710. doi:10.1021/ jp1105168

63. Wang W, Wong NB, Zheng W, Tiang A (2004) Theoretical study on the blueshifting halogen bond. J Phys Chem A 108:1799-1805

64. Krygowski TM, Szatylowicz H, Stasyuk OA, Dominikowska J, Palusiak M (2014) Aromaticity from the viewpoint of molecular geometry: application to planar systems. Chem Rev 114:63836422. doi: $10.1021 / \mathrm{cr} 400252 \mathrm{~h}$

65. Parreira RLT, Galembeck SE (2006) Computational study of pyrylium cation-water complexes: hydrogen bonds, resonance effects, and aromaticity. J Mol Struct THEOCHEM 760:59-73. doi:10.1016/j.theochem.2005.11.020 